\title{
'Study Sessions' of the Second Fifty Years
}

\section{Michael M. Sheehan}

Volume 50, numéro 1, 1983

Bilan de l'histoire religieuse au Canada

Canadian Catholic History: A survey

URI : https://id.erudit.org/iderudit/1007035ar

DOI : https://doi.org/10.7202/1007035ar

Aller au sommaire du numéro

Éditeur(s)

Les Éditions Historia Ecclesiæ Catholicæ Canadensis Inc.

ISSN

0318-6172 (imprimé)

1927-7067 (numérique)

Découvrir la revue

Citer cet article

Sheehan, M. M. (1983). 'Study Sessions' of the Second Fifty Years. Sessions d'étude - Société canadienne d'histoire de l'Église catholique, 50(1), 59-71.

https://doi.org/10.7202/1007035ar

Tous droits réservés @ Les Éditions Historia Ecclesiæ Catholicæ Canadensis Inc., 1983
Ce document est protégé par la loi sur le droit d'auteur. L'utilisation des services d'Érudit (y compris la reproduction) est assujettie à sa politique d'utilisation que vous pouvez consulter en ligne.

https://apropos.erudit.org/fr/usagers/politique-dutilisation/ 


\title{
'Study Sessions' of the Second Fifty Years*
}

\author{
by Michael M. SheEhAN, C.S.B. \\ Pontifical Institute of Mediaeval Studies, Toronto
}

The fiftieth birthday of a man or woman of the twentieth century is not usually regarded as an event of very great significance. In the ordinary course of life much will have been achieved, but it is usually expected that much more remains to be accomplished. On the other hand, the fiftieth anniversary of the individual's adult activities, be they marriage, religious life or the priesthood, a teaching or business career etc., is viewed in a different light. This is a time for reflection on achievement, a time of praise and thanksgiving. There is also an autumnal quality to such an occasion, though it is not our custom to reflect on it. It is tacitly understood that a period of achievement is drawing to a close.

Though it is the part of wisdom to recognize when an institution has come to the end of its usefulness, it is not intended to suggest that the life of the Canadian Catholic Historical Association has run its course. Since institutions are self-replacing groups of individuals, they are potentially of very long life indeed. Even here, however, there are some reasons for apprehension: historians have often remarked that the third generation is a time of special crisis in the lives of great families, religious orders and industrial enterprises. A fiftieth anniversary is an occasion for celebration, for praise and for gratitude but it is not a time for complacency. Perhaps it is in the idea of 'jubilee,' a time of re-examination of the past as a basis for the next step into the future, that the best insight is to be found. It will be remembered that, according to the regulations set out in the book of Leviticus (ch. 25), every fifty years the great horns (yobel) were to be sounded and the Jews

* The author acknowledges, with gratitude, the assistance of his confrere, Rev. A. de Valk, C.S.B., in the preparation of this essay. 
would enter a special season: it was to be a time of renewal, of return to origins, a time to abandon unhappy developments, a time of forgiveness. It is in such a spirit, a spirit of Jubilee, that it is proposed to examine several aspects of the Association's history, to note directions and redirections, to propose shifts of emphasis and thus to suggest the quality of future conferences and publications - the two principal activities of this learned society so deftly described in the charming ambiguity of 'Study Sessions'.

The activities of the Association have been discussed several times during the half century of its life. ${ }^{1}$ There is no need to rehearse those studies here, but one of the themes to which they constantly returned is the implementation of its purpose, and that problem remains of interest. The objects of the Association were set out in the second clause of the Constitution, published in 1934 . While a potential difference of self-understanding was already present in the titles of the two distinct sections created by the Amendments of 30 May, $1934,{ }^{2}$ the two versions of the clause that stated their roles are remarkably close. The encouragement of research, the preservation of significant survivals from the past and the work of publication find equivalent statement in the French and the English versions. There is a slight difference in the object of the public interest that it was intended to stimulate: for the French section it is to be "pour l'histoire de l'Église," while it is to be "in the field of Catholic history" for the English section. ${ }^{3}$ (The latter is capable of considerably wider interpretation as, in fact, developed for a time at least.) This statement of purpose could be appli-

In addition to the frequent references to these matters in Secretary's Reports, note the following: Arthur Maheux, "Où en sommes-nous en fait d'histoire de l'Église canadienne?" Rapport 26 (1959), pp. 13-18; Michael Sheehan, "Considerations on the Ends of the Canadian Catholic Historical Association," Report 30 (1963), pp. 23-31; "Table ronde", ("une discussion autour des objectifs poursuivis et à poursuivre par notre Société"), Sessions d'étude 38 (1971), pp. 85-98; John K.A. O'Farrell, "The Canadian Catholic Historical Association's Fortieth Anniversary : A Retrospective View," Study Sessions 40 (1973), pp. 61-68; Gaston Carrière, "Les quarante ans de la Société Canadienne d'Histoire de l'Église Catholique," Sessions d'étude 40 (1973), pp. 25-32.

${ }^{2}$ Report 1 (1933-4), pp. 92-95.

${ }^{3}$ Ibid. , pp. 92-93. 
cable in many parts of the western world and at several periods of history. It is only by examining its context that it is possible to interpret the objects of the Association with the precision that is desirable. That context and indication of true intent is provided by the first Secretary's Report. The occasion was the meeting of the American Historical Association (AHA) and the American Catholic Historical Association (ACHA) in Toronto, an event like the present one, a fiftieth anniversary; in this case it was that of the AHA. In his Report, James F. Kenney, Secretary of the English Section and principal mover of the whole enterprise, mentioned that the ACHA was modelled on the AHA but differed from it in that it was "devoted chiefly to the history of the Catholic Church." " $\mathrm{He}$ also noted that "The foundation of a like society (italics added) in Canada had often been mooted, but no action taken' until that occasion. These and many other remarks lead to the conclusion that Kenney and his associates saw the ACHA as the model for the Association at least at the moment of foundation. The evolution of the Canadian group away from its American model is of considerable interest from the point of view of developments in the years that lie ahead. It is proposed to devote a few pages to reflections on certain aspects of this trend.

During the two centuries of its life, the American Church has had to weather many controversies as different national groups and their varied traditions have found their place within it. Though that has been and is likely to remain the case, and though there have been several local history societies, the continuation of a single group, the ACHA, has been realized with comparative ease. The consequences of the special circumstances of the Church in Canada, however, made themselves felt immediately: the association was divided to form two sections during the first year. ${ }^{5}$ The implications of that division have slowly unfolded over the years. There has been some gain and some loss. In this Congress the two sections meet together for the first time since 1966. Friends need to see each other more often than that or they run the risk of forgetting the value of their friendship or even that it exists. It is in order, during a time of Jubilee to suggest that the English section should never be complacent about this separation and should always be open to the examination of ways to make common activity more fruitful.

\footnotetext{
${ }^{4}$ Ibid., p. 6.

${ }^{5}$ See "Secretary's Report," Report 2 (1934-5), pp. 7-9.
} 
Another area in which the Association developed away from its American model is in the persons and places from which its activity flowed. Here it is question of a 'secretariat'. Though the English language has adopted the French term with the meaning "an office or department headed by a secretary," it has not adopted the more modern synonym 'permanence' with its overtone of stability and continuity. This permanence is something that the ACHA has had from the beginning. It has always been based at the Catholic University of America. The first Editor of the Catholic Historical Review was the Right Reverend Thomas D. Shahan, titular bishop of Germanicopolis and rector of the University. He maintained that post for fifteen years, continuing after he had become emeritus. During much of that time Rev. Patrick W. Browne was in the background as Managing Editor, but the fact remains that a major academic figure was directly involved in one of the main activities of the ACHA and this, not for a year or two, but long enough to give a direction to its operations. Similarly Rev. Peter Guilday acted as Secretary almost from the beginning and would in time succeed Bishop Shahan as Editor, holding the office for seventeen years. Several other examples of this continuity of direction might be mentioned; let it be sufficient to note that Rev. Robert Triscoe, who is presently Editor of the Catholic Historical Review and Secretary of the Association has held these posts since the autumn of 1962. All of these men held academic appointments at the Catholic University of America. If in these aspects the American model can be seen as a stable and settled people, we have remained herdsmen, moving about, settling where we can, then moving on to the pasture that is green at the moment. This poverty - and it is poverty - has been partly assuaged by the personal dedication of several members. The role of Dr. Kenney has been well described elsewhere, but others like Séraphin Marion and R.P. Edgar Thivierge, O.M.I., who did so much to bring the French section through its first generation, and Conrad Charlebois whose hand steadied both groups from 1955 until but recently, might also be mentioned. The need for a greater stability was frequently discussed at business meetings of the English section during the 1960s but it was only in the mid-seventies that the Executive was able to make steps towards a solution to the problem. First, it was resolved to keep the addresses of the Secretary and the Treasurer as permanent as possible. A Treasurer's address, has been located at the Curial House of the Basilian Fathers or at St. Basil's College in Toronto for the past decade, even though individual Treasurers have come and gone. The Secretary at that time was Mrs. Joan Lenardon and she did much to strenghthen the Association by her steady attention to correspondence 
and other business as it arose. After her resignation in 1979, Rev. Edward Jackman O.P., then the Vice-President, accepted the secretaryship as well. Since that time he has also assumed the offices of President and President-General in turn while maintaining the all important function of Secretary. His continued interest and generosity have much to do with the comparatively strong position that the Association enjoys at the moment. A second development of the same period was related to Study Sessions. It was decided to seek an Editor who would accept the post for a reasonably long period. ${ }^{6}$ This task was accepted in 1974 by Rev. Alphonse de Valk, C.S.B., shortly before he also found it necessary to assume the vice-presidency following the sudden death of Stephen Gradish, a young colleague at St. Thomas More College, Saskatoon. At the same time, it was resolved that an on-going committee, consisting of the Editor and the President and Vice-President of the Association, would design the annual program, arranging for papers well in advance of the time of their delivery. This arrangement has continued to the present and its success is obvious: with the appearance of Study Sessions, volume 50, Fr. de Valk will have edited his tenth volume of the series. Selection of only a few individuals, when several others have contributed mightily to the life of the Association, runs a grave risk of being invidious. The question at issue here, however, is the continuity and consistency of purpose that the ACHA has so well demonstrated and the way in which the English section has returned to that model. If this trend can be maintained, even carried further, the future will be full of promise.

It has been remarked more than once that the foundation and growth of the association should be related to that broader context of study in which the history of the Church has assumed ever greater importance. ${ }^{7}$ During the years in which the English section made those promising adjustments that have just been discussed, major events, the impact of new media and shifting attitude to historical knowledge have made significant changes in the context in which the Association functions. Perhaps most important is the fact that the Church has passed through the crucible of the Second Vatican Council. The invitation to a better understanding of the Church's past as a key to its future was issued

\footnotetext{
${ }^{6}$ Discussions along similar lines occurred in 1964 : Report 31 ( 1964 ), pp. 10.

${ }^{7}$ Among others note, Michael Sheehan, "Considerations", Report 30 (1963), pp. 23-25.
} 
at the beginning of the Council and is still being uttered to those who would listen. Now, after almost twenty years, it becomes clear that the historian's perspective is needed to assist in the understanding of the rapid changes that have occurred. The prime object of the Association, 'To encourage historical research,' takes on an urgency that it has not had before. An important step was taken on April 6, 1967 with the launching of the Centre de Recherche en Histoire Religieuse du Canada at Université Saint-Paul, Ottawa. The Centre was founded after careful planning and has proceeded quietly and with deliberation. It has already made significant contribution to the province of source collections and the instruments of research. The publication of Guide Sommaire des Archives des diocèses catholiques au Canada / Abridged Guide to the archives of Catholic Dioceses of Canada and Évêques catholiques du Canada 1685-1979 / Canadian R.C. Bishops 1658-1979 is an example of the indispensible tools that the Centre is providing for the researcher. This research centre, an institution of great promise, is not directed related to the Canadian Catholic Historical Association but the principal founders and those who have been active there, have also been members of the Association, especially of the French Section. The interest in the history of the Church in Canada that the Association fostered over the years has probably contributed significantly to the establishment and continued activity of the Centre.

At another level, that of research and instruction within Canadian universities, the situation is uneven. Several developments have proved very helpful: the examination of religious phenomena by departments of sociology and anthropology and the rapid growth of interest in social history have helped Church historians to discover new dimensions to their study, underlining the importance of research in the history of religious practice and pastoral care. Scholars from university departments often react against the older work of "clerico-nationalist historians", 8 an attitude most often to be observed in the province of Quebec but to be seen in much of the rest of the country as well. It is perhaps indicative of attitudes and also of a serious lack in the quality of many studies of various aspects of the history of the Church that in Perspectives on the Social Sciences, published in 1974, Ramsey Cook's essay "History the Invertebrate Social Science," found little to mention that related to

\footnotetext{
${ }^{8}$ Quoted from David Gagan and H.E. Turner, "'Social History in Canada : A Report on the 'State of the Art,"' Archivaria 14 (Sept. 1982), p. 35.
} 
Canadian religious history among serious studies of the time. ${ }^{9}$ Yet "A Current Bibliography of Canadian Church History," published in Study Sessions of the previous year listed more than 380 items. In part the discrepancy is to be explained by a difference of perspective - an essay or a monograph can sometimes be seen as descriptive of society, or of religious structures (which often are societies), or of religious practice - but the quality of the literature in question must also be considered. As it happens, one of the main sources for much of the socio-historical research of the moment is provided by the documentation created by parish, diocesan chancery and the institutions directed by religious orders, that is, by the main institutions through which the Church has functioned. ${ }^{10}$ The exploitation of this material in many studies currently under way in Quebec universities is surely one of the brighter areas of academic activity in Canada. In the Church History departments of theology faculties of English-speaking Canada there has been significant research and publication on the history of the Protestant Churches and the Anglican Church in Canada, but little has been produced on the Catholic Church, a situation that is to be explained by the fact that, while a significant number of historians in Catholic institutions study the history of the Church, only a few of them work on the history of the Canadian Church. Theses tend to be written in the areas in which professors are most active.

Within other elements of Canadian society there are tendencies that are at once a threat and an opportunity. Few would question the statement that, for about twenty years, there has been a diminishing of historical knowledge among secondary-school graduates and a noticeable impatience with the discipline necessary for historical studies at the undergraduate level of the University. While the understanding of our true past and the difficult work demanded of those who would attain it have been in retreat, there is a quickening of interest in a somewhat simplified and idealized, not to say a radically adjusted view of the past. The popularity of the historical dream, so evident in the extraordinary success of several films and historical novels in recent years, and of movements characterized by the Society for Creative Anachronism are evidence of this fact. The long established practice of those who use

\footnotetext{
${ }^{9}$ T.N. Guinsburg and G.L. Reuber, eds., Perspectives on the Social Sciences in Canada, 1974, pp. 128-149.

${ }^{10}$ See Archivaria 14 (Sept. 1982), a special number entitled "Archives and Social History."
} 
the past to belabour the opponent of the present - a fault from which Church historians have not been free - is still with us and is especially dangerous in the conditions of a Church that wrestles with the consequences of the Second Vatican Council. In this combination of interests history can become a flight from the present rather than a light for it. On the other hand, it is important to note that, while there may be a loss of interest of history that studies the activities of those in positions of power, there is a growing attraction to the past of the ordinary members of society and in the material evidence of their lives. This might be called a 'Roots phenomenon', typified as it has been by the remarkable success of recent presentations of the history of the Black races of America. In English-speaking Canada this kind of interest is more recent than in Quebec, but now at last there is a growth of historical inquiry focused on the pioneer village, the care and renewal of older cemeteries and the restoration of churches. The role of the wrecker's ball in the reconstruction of our cities is subsiding at last. At the same time there has been an ever widening search of records in an effort to reconstruct the history of ordinary families. All of this points to broadly based tendencies within our society that are of much promise for those who would "encourage public interest in the field of Catholic history."

\section{$* * *$}

In the face of these ambivalent attitudes to the history of the Church, the English Section has made several adjustments in its approach to the realization of its objectives, adjustments that will likely control the direction of 'Study Sessions' for years to come. The changes can be summarized in a sentence: objectives will be realized if the English Section becomes more professional and more Canadian. In terms of the membership of its executive, the English Section had been largely professional from the beginning, but further consequences of the professionalism remained to be explicated. In 1961 the Association began to meet with the Learned Societies. ${ }^{11}$ In both short and long terms, the decision has had regrettable consequences. It meant that the meetings in French- and English-speaking Canada on alternate years had to be abandoned, since the Learned Societies, much more "Canadian" in outlook than our Association had managed to be, has tried to visit all parts of the country. Thus most of its meetings have been

\footnotetext{
${ }^{11}$ See the discussion minuted in “'Secretary's Report," Report 27 (1960), p. 12.
} 
held in English-speaking centres. Furthermore, under these new conditions, local support for programs and attendance at meeting were difficult to maintain so that there was a serious diminishing of subscriptions. By 1966 the French Section had decided that the decision had been an error and reverted to the older practice, gathering in Frenchspeaking parts of Canada, especially in Quebec. ${ }^{12}$ This meant the end of the joint meeting that had been characteristic of the Association and that has been renewed in 1983 as part of the present Jubilee. On the positive side, the decision to meet with the Learned Societies meant that the Association was seen to function in all parts of the country so that, by a strange kind of irony, the English Section found itself being more fully "Canadian" in outlook than the French Section proved to be, even though the different colouring of the titles of the two sections might have been interpreted to mean the opposite. Furthermore, the arrangement made it possible to broaden the academic relationships maintained by the Association. Exploiting the opportunity afforded, it began a series of highly successful meetings with the Canadian Historical Association. These joint sessions were abandoned in the early 1970s because of the difficulty in arranging them and because of the changed format of meeting adopted by the Canadian Historical Association, a setback that, it is hoped, will not prove to be permanent. Shortly afterwards a joint meeting was arranged with the Canadian Church History Society. This ecumenical session has become a regular feature of the meetings of the English Section and has proved to be successful both in program and in attendance. The papers read by members of the Canadian Church History Society at the meetings of 1981 and 1982 were published in Study Sessions. ${ }^{13}$ These and other indicators suggest that this cooperation has a promising future. Thus the decision to join the Learned Societies and meet with them has already borne fruit in the exploitation of the opportunity of association with other professional societies. The logic of this development might well lead to closer relationships with social historians, anthropologists and sociologists, in a word, with groups of scholars whose research has led them into fields cognate with that of the Church historians. It is already evident that,

\footnotetext{
${ }^{12}$ The loss of local interest was discussed in Rapport 30 (1963), p. 9.

${ }^{13}$ John Moir, "Canadian Protestant Reaction to the Ne Temere Decree," Study Sessions 48 (1981), pp. 79-90, and Tom Sinclair-Faulkner, "Sacramental Suffering, Brother André's Spirituality," 49. (1982), pp. 111-134.
} 
on a personal basis, such cooperation has been fruitful; the wider contacts made possible by joint sessions might prove useful to all concerned. ${ }^{14}$

The move towards a more professional approach in the activity of the Association was reinforced by a decision to focus the interest of the English Section more fully on the Canadian Church. From the beginning, like its model the ACHA, the English Section had been interested in the life of the Church in all periods and in all areas. A symptom of the attitude that prevailed is to be found, perhaps, in the fact that the first article published by Report was "Dante, the Poet of the Liturgy," by Mary Manley. ${ }^{15}$ On occasion, there were lectures and publications, some of major importance, ${ }^{16}$ that reflected the work of Catholic historians that had little or nothing to do with the history of the Church. This policy reflected the situation mentioned above: while there were many Catholic historians in Canada, few were specialists in Canadian Church history. At the same time, it is important not to overemphasize this trend. During the first twenty-five years the vast majority of the articles published in Report dealt with the Church in Canada, a high proportion of them being short biographical treatments of its leaders both clerical and lay. But between 1958 and 1971, considerably more than half the articles dealt with themes that were not related to Canada. In fact, Volumes 28 and 29, for 1960 and 1961 respectively, contain no English articles that discuss the religious life of Canada; this was the period when the decision was being made to join the Learned Societies. A different approach soon began to manifest itself, however, when a current bibliography of Church history was launched in 1964 with the intention that it become an annual feature of the Report. ${ }^{17}$ It was planned that this bibliography would gather publications on all aspects of religious history (Christian, Jewish and other religious groups), in French, English and other languages, but it was to deal only with Canada. ${ }^{18}$ With the exception of an interruption in 1974, this work entitled "A Current Bibliography of Canadian

\footnotetext{
${ }^{14}$ See the special number of Archivaria and Perspectives in Social Sciences, passim.

${ }^{15}$ Report 1 (1933-4), pp. 12-21.

${ }^{16}$ E.g. J.A. Raftis, "The Trends toward Serfdom in Mediaeval England," Report 22 (1955), pp. 15-25, a seminal article on the history of the peasant.

${ }^{17}$ See "Minutes of the Annual Meeting...," Report 31 (1964), p. 9.

${ }^{18}$ Here there is a turning away from the model provided by the Catholic Historical Review which, in its reviews of books and short notices, takes the whole history of the Church as its purview.
} 
Church History / Bibliographie récente de l'Histoire de l'Église canadienne," has appeared since Volume 31 of Report and has continued in Study Sessions. With the publication of the eighteenth instalment it comprises more than $\mathbf{4 7 0}$ closely printed pages of bibliographies, sources, articles and monographs on all aspects of the religious life of Canada. As the bibliography increased in size - that of 1982 is thirty-eight pages -, the French Section began to share the cost of publication, providing assistance without which it is unlikely that this service to scholarship could have been continued.

The transition to a full slate of Canadian papers took longer to achieve, but a noticeable shift in that direction is evident by 1972 . Two years later the English Section decided to restrict itself to the history of the Canadian Church. This was not easy to achieve, but long term plans were made and implementation was begun at once. Study Sessions for 1975 and 1976 only contain papers touching the Canadian Church, six and five of them respectively. There was one paper read at the meeting in 1976 that had been arranged before the change of policy and that did not meet the 'Canadian' qualification. (It was not printed until 1977 because of limitations of space and funding. ${ }^{19}$ ) With that exception 'Study Sessions' have been exclusively concerned with the Canadian Church since 1975. Thus after drawing very close to the pattern of publication by the Catholic Historical Review during the 1960s, the English section changed its policy so as to make the Canadian Church its area of research and publication, a policy that has been maintained by the French Section from the beginning.

Related to this adjustment of policy was the decision that program committees should not be content with essays that scholars happened to offer, but that a rationale should be developed according to which papers would be sought well in advance of the program as part of which they would be delivered. It was decided that each year there should be a study of one of the religious congregations that exercised its apostolate in English-speaking Canada with emphasis, where possible, on the social effect of their activity. The first of this series was a study of the Sisters of Service in $1976 ;{ }^{20}$ it has continued to the present.

\footnotetext{
${ }^{19}$ Anne Wyatt, "The Portrayal of the Irish in Lingard's History of England," pp. 77-95.

${ }^{20}$ Ella Zink, "Church and Immigration: The Sisters of Service, English Canada's first missionary Congregation of Sisters, 1920-1930," pp. 23-38.
} 
The transition from the point of view that concentrated on the interior development of an institution to that which would see it in terms of its function within the local Church and in the wider society is not an easy one and has been achieved with varying degrees of success. But a direction has been given to this type of study that is rich in promise for the future.

It was also intended that, in the context of the vast process of adjustment and development in which the Church had been engaged since the beginning of the Second Vatican Council, there should be an annual paper that would seek to interpret current changes from a historical point of view, estimating the degree to which they represent innovation and their likely consequences. This important enterprise has been less successfully maintained though significant contributions have been made. ${ }^{21}$ As the decisions of the Council begin to be implemented in institutional terms - thus the new Codex iuris canonici promulgated in 1983, the revised constitutions of several religious orders, etc. - the need for an historical interpretation of quite recent events will become even more evident; there is reason to expect that the plan that has proved difficult to realize will come to fruition. In more general terms, the decision to proceed according to a rationale so that, as much as possible, areas of need can be identified and studied by the historian in a systematic manner, seems correct. Always remaining on guard against becoming involved in ephemera, the Association would be wise to exploit the possibilities of the direction it has begun to take.

One of the objects of the Association has been "To promote the preservation of historical sites and buildings, documents, relics, and other significant heirlooms of the past." Within these areas, it has seen ecclesiastical archives to be its special charge, and various reports and articles over the years have returned to the discussion of their importance and the necessity that they be catalogued and made available to scholars. ${ }^{22}$ On the whole, the publication record of the Association

\footnotetext{
${ }^{21}$ See Kevin J. Kirley, "A Seminary Rector in English Canada during and after the Second Vatican Council," Study Sessions 43 (1976), pp. 57-74; Stephen Somerville, "Language, One or Many, in the Liturgy since Vatican II," 44 (1977), pp. 97-109; and Alphonse de Valk, "Understandable but Mistaken, Law, Morality and the Canadian Catholic Church 1966-69," 49 (1982), pp. 87-109, and "Secularism, Law and Society in Canada 1969-1982 : a Sketch," read during the 50th annual Study Sessions at the University of British Columbia 7 June, 1983.

${ }^{22}$ This preoccupation is evident in the earlier Secretary's Reports; see Sheehan, “Considerations," Report 30 (1963), p. 26.
} 
has not been impressive in this regard: there have been eleven descriptions of archives in fifty years. Yet there has been progress: the Guide published by the Centre de Recherche en Histoire Religieuse du Canada, mentioned above, the efforts being made in many chancery offices to prepare at least a preliminary catalogue of archives and provide accommodation for the scholars who would use them, and the fact that several religious orders have made serious commitments of resources to their archives are among the positive steps that are evidence of that progress. Though the Association as such has not been the cause of these improvements, its members have played major roles in them. It is not unreasonable to think that the Associations frequently expressed, though only partially fulfilled, desire that more attention be given to archive management has been effective indirectly. In a similar way, where efforts have been made to provide better and more rationalized care for the important monuments of the past life of the Church, the Association has not been active, but its members - its PresidentGeneral, Fr. Jackman is a good case in point - have played important roles in these matters. As the meetings of the Association move about the country with the Learned Societies it might be possible to develop an architectural parallel to the description of an archive that has occasionally been possible; that is, to prepare a brief description of the significant sites and monuments of a region according to a concise and stylized form, so that it might be included in the relevant volume of Study Sessions. In this way the Association would assist in that focussing of public interest that is necessary of the heirlooms of our past are to be preserved.

All in all, it becomes clear enough that the last twenty years, more especially the last decade, have seen the English Section of the Association redirect itself in several ways: it has drawn closer to the stable base of organization that the ACHA has enjoyed from the beginning but, in its activity, it has abandoned the model of that society by concentrating its research and publication on a narrower subject, the history of the Canadian Church. This recent past has established likely lines of development for years to come. It is not excessive to see in them the substance of the 'Study Sessions' of the years until the next Jubilee. 